\section{C- REACTIVE PROTEIN IN PATIENTS WITH NSTEMI ACUTE CORONARY SYNDROME}

Dubey $\mathrm{RK}^{*}$, Dhakal $\mathrm{N}^{* *}$, Das $\mathrm{BKL}^{* *}$, Pandey $\mathrm{NK}^{* * *}$, Baral $\mathrm{N}^{* *}$, Lamsal $\mathrm{M}^{* *}$

*Department of Biochemistry, Universal College of Medical Sciences, Bhairahawa, Nepal ${ }^{* *}$ Department of Biochemistry, ${ }^{* *}$ Department of Internal Medicine B. P. Koirala Institute of Health Sciences, Dharan, Nepal

Email:- rajukd85@gmail.com

\section{ABSTRACT}

Background: C- reactive protein (CRP) is an acute phase inflammatory mediator that has been implicated as a risk factor for cardiovascular disease (CVD). The clinical presentation of acute coronary syndrome (ACS) ranges from unstable angina (UA) to non ST- segment elevation myocardial infarction (NSTEMI) and ST- segment elevation myocardial infarction (STEMI). Although, elevated levels of serum CRP have been reported in patients with CVD, the serum levels of CRP in patients with NSTEMI ACS is unknown. The purpose of the study was to determine whether the serum levels of CRP are higher in patients with NSTEMI ACS as compared to healthy controls.

Methods: The study subjects consisted of two groups. Group I: (controls) twenty- five age-matched healthy men and Group II: Forty- five NSTEMI ACS patients. Fasting blood samples were collected and serum levels of CRP were measured by using highly sensitivity immunoassay rate method technology.

Results: The serum levels of CRP in Group I and Group II were $3.2 \pm 0.25$ and $11.32 \pm 2.1 \mathrm{mg} / \mathrm{L}$, respectively and these values were significantly different from each other $(p<0.05)$. Group II showed a $253 \%$ higher level of CRP as compared to Group I subjects.

Conclusion: The results demonstrate that the serum levels of CRP are higher in patients with NSTEMI ACS as compared to controls. Serum CRP levels are elevated in patients with NSTEMI ACS and may contribute to the inflammation and thrombosis associated with acute coronary syndrome.

\section{INTRODUCTION}

Numerous avenues of research ranging from basic experimental evidence to population-based observational studies have led to the recognition that CVD has many features of a systemic inflammatory process. Inflammation is a key element of the atherosclerotic process and contributes to all of its stages, from plaque initiation to subsequent growth and eventual rupture..$^{2,3,4}$ Highsensitivity C-reactive protein (hsCRP) is an easily measured and widely investigated biomarker of inflammation. It is unclear whether CRP itself directly contributes to the pathophysiology of CVD. Supporting data for a role for CRP in atherothrombosis is limited to in vitro studies and experiments with animal models. ${ }^{5,6}$ Pepys et al. found that specific inhibition of CRP is feasible with a small-molecule synthetic compound [1,6-bis(phosphocholine)- 
hexane], which produces smaller infarct sizes in rats. ${ }^{7}$ Regardless of whether CRP plays a causal role in atherothrombosis, this biomarker has been proposed to be useful for improving CVD-risk prediction.

Although, elevated levels of serum CRP have been reported in patients with CVD, the serum levels of CRP in patients with NSTEMI ACS is unknown. The purpose of the study was to determine whether the serum levels of CRP are higher in patients with NSTEMI ACS as compared to healthy controls.

\section{MATERIALS AND METHODS:}

This cross-sectional study was carried out in the Department of Biochemistry with collaboration of Department of Internal Medicine, B.P. Koirala Institute of Health Sciences, Dharan, Nepal. The study population was comprised of Group I and Group II. Group I was comprised of twenty- five age-matched healthy men as controls and Group II was comprised of forty- five NSTEMI ACS patients admitted to our coronary care unit with unstable angina or acute myocardial infarction. Inclusion criteria were typical chest pain and non ST elevation in at least two contiguous electrocardiographic leads, elevated cardiac troponin levels, or angina at rest following myocardial infarction within 2 weeks in patients with unstable angina. Fasting blood samples were collected and serum levels of CRP were measured by using highly sensitivity immunoassay rate method technology. The assay is reported to have a minimum detectable concentration of 0.00035 $\mathrm{mg} / \mathrm{L}$. At a concentration of 0.003 $\mathrm{mg} / \mathrm{L}$, our inter-assay precision was $7.4 \%(n=20)$.

\section{STATISTICAL ANALYSIS:}

Data are presented as means \pm S.D. Categorical variables were analyzed with chi-square test and continuous variables with Student's t-test. A p value $<0.05$ was considered statistically significant.

\section{RESULTS:}

The sample consisted of 70 individuals. The mean age (year) of group I is $51 \pm 8$ and that of group II is $53 \pm 7$. The age difference between group I and group II is not statistically significant $(p>0.05)$ showing the matching of cases and controls. The serum levels of hsCRP in Group I and Group II were $3.2 \pm 0.25$ and $11.32 \pm$ $2.1 \mathrm{mg} / \mathrm{L}$, respectively and these values were significantly different from each other $(p<0.05)$ as shown in figure 1. Group II showed a $253 \%$ higher level of hsCRP as compared to Group I subjects.

Figure1: hsCRP levels in controls and cases

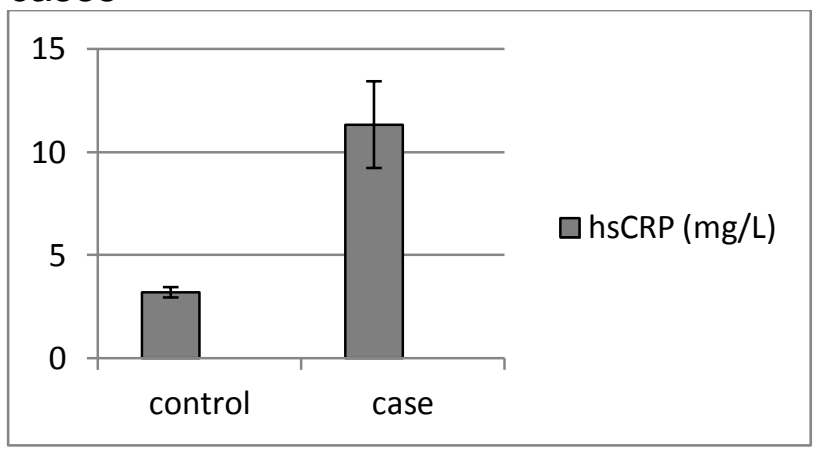

\section{DISCUSSION:}

In the present study, we investigated the levels of hsCRP in patients with NSTEMI ACS as the inflammatory marker. As a result of our analysis, hsCRP level is significantly higher in patients group as compared to normal healthy adults $(p<0.005)$. In the Kennon et al. study, ${ }^{8}$ CRP levels were evaluated in patients with ACS and non-ST elevation on admission and after 12, 24 and $48 \mathrm{~h}$; they shifted from a mean of 4.5 to one of $4.72,7.79$ and 9.99 respectively, with a statistically 
significant difference between patients taking and not taking aspirin prior to the onset of symptoms. In the study of James et al. $^{9}$, CRP was assessed in patients with ACS (angina, positive troponin (Tn) T or Tn I tests and ST depression $\geq 5 \mathrm{~mm}$ ) at baseline and after 8, 16, 24, 36 and $48 \mathrm{~h}$ after randomization. CRP levels ranged between 0 to $489 \mathrm{mg} / \mathrm{dl}$. Cusack et al. ${ }^{10}$ reported mean CRP levels in ACS at baseline, $6,24,48 \mathrm{~h}$ and 7 days: there was an increase after $48 \mathrm{~h}$ and a reduction below baseline levels after 7 days. In patients with NSTEMI, CRP plasmatic concentration significantly increased at 48 and $72 \mathrm{~h}$, even if administration of tirofiban lowered rise of CRP levels. ${ }^{11}$ Similar release curves were identified by other authors also in patients with $\mathrm{AMI}^{12}$ with peak concentration on third day after MI. ${ }^{13}$

In patients with UA, persistent or worsening symptoms and signs of ischemia despite full medical therapy indicate a poor prognosis, ${ }^{14,15,16}$ However, at the time of hospital admission, it is not possible to predict whether UA will remit or progress to myocardial infarction, because the causes of instability and the mechanisms underlying its evolution are not known. A role for inflammation in UA is suggested by histological studies of unstable coronary plaques, ${ }^{17,18}$ evidence of the systemic release of thromboxanes and leukotrienes, ${ }^{19,20}$ and the presence of activated circulating leukocytes. ${ }^{21,22}$ Furthermore, increased concentrations of plasma CRP, the prototypal acutephase reactant, have been reported in some patients with $U^{23,24}$ in patients with coronary artery disease and other types of angina, ${ }^{25}$ and in 20 percent of patients who have an AMI within six hours after the onset of symptoms, before any elevation of myocardial enzyme levels in serum. ${ }^{26}$ The acutephase reactants are very sensitive, although nonspecific, markers of inflammation. In patients with severe UA, elevated plasma levels of CRP are associated with an unfavourable shortterm prognosis. ${ }^{27}$

Traditional risk factors of CVDs include aging, hypertension, dyslipidemia, smoking and diabetes mellitus. Among these risk factors, dyslipidemia plays an important role in the formation of atheromatous lesions, which ultimately cause stenosis or occlusion of arterial lumens. In addition to lipid accumulation, laboratory and experimental evidence indicate that chronic inflammatory process takes part in the development of atherosclerosis. ${ }^{3} \mathrm{~A}$ number of studies have examined various circulating markers of inflammations, such as cytokines and adhesion molecules, as potential predictors of the present and the future risk of CVDs of the numerous circulating markers thus far studied, hsCRP seems to have the most consistent relation to the risk of CVDs in a variety of clinical settings, including healthy subjects ${ }^{28,29}$ selected high-risk subjects with traditional risk factors $^{30}$ and patients with CVDs. ${ }^{31}$ Therefore, currently, measurement of circulating hsCRP seems to provide a reproducible, reliable and feasible index of inflammation and cardiovascular risk compared with other inflammatory markers.

\section{CONCLUSION:}

The results demonstrate that the serum levels of CRP are higher in patients with NSTEMI ACS as compared to controls. Serum CRP levels are elevated in patients with NSTEMI ACS and may contribute to the inflammation and thrombosis associated with acute coronary syndrome. Assuming that plasma hsCRP reflects future risk of CVDs, intervention which reduces CRP may be effective in preventing the 
occurrence of cardiovascular events. Serial evaluation of CRP plasmatic concentration may help in risk stratification of patients with ACS.

\section{ACKNOWLEDGEMENT:}

We thank the faculty members and staff of the Department of Biochemistry and Medical OPD, B. P. Koirala Institute of Health Sciences, Dharan, Nepal.

Conflict of Interest: The authors have no conflicts of interest with the material presented in this paper.

\section{References:}

1. Libby $P$, Ridker $P M$, Maseri $A$. Inflammation and atherosclerosis. Circulation 2002; 105:1135- 43.

2. Hansson GK. Inflammation, atherosclerosis, and coronary artery disease. $N$ Engl $J$ Med 2005;352:1685-95.

3. Ross R. Atherosclerosis-an inflammatory disease. $N$ Engl J Med 1999;340:115-26.

4. Libby $P$, Ridker PM. Inflammation and atherothrombosis from population biology and bench research to clinical practice. J Am Coll Cardiol 2006;48(Suppl):A33- 46.

5. Scirica BM, Morrow DA. Is C-reactive protein an innocent bystander or proatherogenic culprit? The verdict is still out. Circulation 2006; 113:212834, discussion 2151.

6. Verma S, Devaraj S, Jialal I. Is Creactive protein an innocent bystander or proatherogenic culprit? C-reactive protein promotes atherothrombosis. Circulation 2006; 113:2135-50, discussion 2150.

7. Pepys MB, Hirschfield GM, Tennent GA, Gallimore JR, Kahan MC, Bellotti $V$, et al. Targeting C-reactive protein for the treatment of cardiovascular disease. Nature 2006;440:1217-21.

8. Kennon S, Price CP, Mills PG, et al. The effect of aspirin on C-reactive protein as a marker of risk in unstable angina. J Am Coll Cardiol 2001(April);37(5):1266-70.

9. James SK, Armstrong P, Barnathan E, et al. Troponin and C-reactive protein have different relations to subsequent mortality and myocardial infarction after acute coronary syndrome: a GUSTO-IV sub study. J Am Coll Cardiol 2003 (March 19); 41(6):916 24.

10. Cusack MR, Marber MS, Lambiase $P D$, Bucknall CA, Redwood SR. Systemic inflammation in unstable angina is the result of myocardial necrosis. J Am Coll Cardiol 2002 (June 19); 39(12):1917- 23.

11. Ercan E, Tengiz I, Duman C, Onbasili OA, Baris N. Effect of tirofiban on Creactive protein in non-ST-elevation myocardial infarction. Am Heart J 2004(January);147(1):54-7.

12. Berton G, Cordiano $R$, Calmieri $R$, Pianca S, Pagliata $V$, Palatini $P$. Creactive protein in acute myocardial infarction: association with heart failure. Am Heart J 2003;145:1094101.

13. Gabriela AS, Martinssona A, Wretlindb $B$, Ahnvea S. IL-6 levels in acute and post myocardial infarction: their relation to CRP levels, infarction size, left ventricular systolic function, and heart failure. Eur $J$ Intern Med 2004;15:523- 8.

14. Mulcahy R, Daly L, Graham I, et al. Unstable angina: natural history and determinants of prognosis. $A m \mathrm{~J}$ Cardiol 1981; 48:525-8.

15. Gottlieb SO, Weisfeldt ML, Ouyang P, Mellits ED, Gerstenblith $G$. Silent ischemia as a marker for early unfavourable outcomes in patients with unstable angina. $N$ Engl $\mathrm{J}$ Med 1986; 314:1214-9.

16. Langer $A$, Freeman MR, Armstrong $P W$. ST segment shift in unstable angina: pathophysiology and 
association with coronary anatomy and hospital outcome. J Am Coll Cardiol 1989; 13:1495-502.

17. Kohchi K, Takebayashi S, Hiroki T, Nobuyoshi M. Significance of adventitial inflammation of the coronary artery in patients with unstable angina: results at autopsy. Circulation 1985; 71:709-16.

18. Sato T, Takebayashi S, Kohchi K. Increased sub endothelial infiltration of the coronary arteries with monocytes/macrophages in patients with unstable angina: histological data on 14 autopsied patients. Atherosclerosis 1987; 68: 191-7.

19. Vejar M, Fragasso $G$, Hackett $D$, et al. Dissociation of platelet activation and spontaneous myocardial ischemia in unstable angina. Thromb Haemost 1990; 63:163-8.

20. Ciabattoni G, Ujang S, Sritara $P$, et al. Aspirin, but not heparin, suppresses the transient increase in thromboxane biosynthesis associated with cardiac catheterization or coronary angioplasty. J Am Coll Cardiol 1993; 21:1377-81.

21. Serneri GG, Abbate R, Gori AM, et al. Transient intermittent lymphocyte activation is responsible for the instability of angina. Circulation 1992; 86:790-7.

22. Mazzone A, De Servi S, Ricevuti G, et al. Increased expression of neutrophil and monocyte adhesion molecules in unstable coronary artery disease. Circulation 1993; 88:358-63.

23. De Beer FC, Hind CRK, Fox KM, Allan RM, Maseri A, Pepys MB. Measurement of serum C-reactive protein concentration in acute myocardial infarction. Br Heart J 1982; 42:239-43.

24. Berk BC, Weintraub WS, Alexander $R W$. Elevation of C-reactive protein in "active" coronary artery disease. Am J Cardiol 1990; 65:168-72.

25. Juhan-Vague I, Alessi MC, Joly $P$, et al. Plasma plasminogen activator inhibitor-1 in angina pectoris: influence of plasma insulin and acute-phase response. Arteriosclerosis 1989;9:3627.

26. Andreotti $F$, Roncaglioni MC, Hackett $D R$, et al. Early coronary reperfusion blunts the procoagulant response of plasminogen activator inhibitor-1 and von Willebrand factor in acute myocardial infarction. J Am Coll Cardiol 1990;16:1553-60.

27. Liuzzo G, Biasucci LM, Gallimore JR, et al. Prognostic value of $C$-reactive protein and plasma amyloid $A$ protein in severe unstable angina. $N$ Engl $J$ Med 1994;331:417-24.

28. Ridker PM, Cushman M, Stampfer MJ, Tracy $\mathrm{R}$, Hennekens $\mathrm{CH}$. Inflammation, aspirin, and the risk of cardiovascular disease in apparently healthy men. New Engl J Med 1997;336:973-9.

29. Ridker PM, Hennekens $\mathrm{CH}$, Buring JE, Rifai N. C-reactive protein and other markers of inflammation in the prediction of cardiovascular disease in women. New Engl J Med 2000;342:836-43.

30. Kuller LH, Tracy RP, Shaten J, Meilahn EN. Relation of Creactive protein and coronary heart disease in the MRFIT nested case-control study. Multiple Risk Factor Intervention Trial. Am J Epidemiol 1996;144:537-47.

31. Haverkate F, Thompson SG, Pyke S, Gallimore JR, Pepys MB. Production of C-reactive protein and risk of coronary events in stable and unstable angina. European Concerted Action on Thrombosis and Disabilities Angina Pectoris Study Group. Lancet 1997;349:462-6. 